\title{
INSTITUTIONAL INFRASTRUCTURE OF FINANCIAL SUPPORT FORMATION FOR LIGHT INDUSTRY ENTITIES
}

\section{Mykola Denysenko ${ }^{1}$, Ludmila Seliverstova ${ }^{2}$}

${ }^{2}$ Doctor of Science (Economics), Professor of Business Economics and Tourism Department, Kyiv National University of Technology and Design, Kyiv, Ukraine, e-mail: profden3@gmail.com, ORCID: https://orcid.org/0000-0001-8767-9762

${ }^{2}$ Doctor of Sciences (Economics), Professor, Professor of the Department of Finance, Kyiv National University of Trade and Economics, Kyiv, Ukraine, e-mail: drls25@ukr.net, ORCID: https://orcid.org/0000-0002-2231-0558

Effective activity of economic entities is one of the most important modern features of a market economy and a basic prerequisite for the development of the national economy of any country in the world, regardless of its level of development. Today there is a process of gradual integration of Ukraine into the European Union with its specific harsh market conditions, which pose a survival problem for domestic economic entities. An analysis of the dynamics of the number of economic entities shows that this sector in Ukraine is on the stage of development and formation. In the current situation, business development in Ukraine should be a decisive factor for improving economic mechanisms: this direction requires effective state support, which should be aimed at creating a positive economic and legal climate.

A special place in the Ukrainian economy belongs to the industry, which is the basis of material production sphere, it plays an important role in the formation of both productive forces and industrial relations. Industry is playing an increasingly important role in creating new jobs, developing competition and fostering the country's economic growth by generating a large portion of national income and gross domestic product. Light industry is a component of the Ukrainian manufacturing industry and the multidisciplinary sector of the economy, which plays an important role in ensuring economic and strategic security, employment and raising its standard of living. An important feature of this type of economic activity is the rapid turnover of capital, which is $2-5$ times a year, because of the short production and sale of products. Due to the possibility of using local raw materials (wool, flax, leather), the development of light industry contributes to the development of the most important agricultural production areas.

Light industry is a type of activity that shapes the budget of many countries of the world and fills the domestic market with products of its own production. For Ukraine, light industry is an important kind of industrial activity, since its main task is to provide the population with fabrics, clothing, footwear, etc., and other industries - cord, technical fabrics, medical materials, etc. Light industry can be attributed to the main branches of social orientation, most of this industry products are essentials, the development of which is a prerequisite for improving the standard of the population 
living [1, p. 167]. As this sector has a social orientation, it is one of the most important components of economic development [2].

According to the opinion of domestic and international experts, Ukrainian light industry has huge potential. There are more than 2.3 thousand light industry enterprises in the country with about 85 thousand employees. Light industry of Ukraine is gradually increasing its capacity, and its indicators have been steadily increasing for several years in a row. The country is actively developing textile, garment, knitwear, leather footwear, leather goods, fur and other areas.

According to the results of 2016, clothing production accounted for about $40 \%$ of all sales, textile production - $37 \%$, leather and footwear - more than $20 \%$. At the beginning of 2017, the regional rating of light industry production was topped by the Lviv region (14.4\%), followed by Zhytomyr (8.7\%), Kharkiv (8.5\%), Dnipropetrovsk (7\%) and Kiev (6.9\%). Thanks to quality tailoring and democratic prices, the Ukrainian manufacturer's clothing is gaining popularity not only in the domestic but also in the international market [3].

The share of light industry in the country's GDP exceeds $1 \%$, while in developed countries it exceeds $10-20 \%$.

The dynamics of light industry goods exports for 2011-2017 are shown in fig. 1.

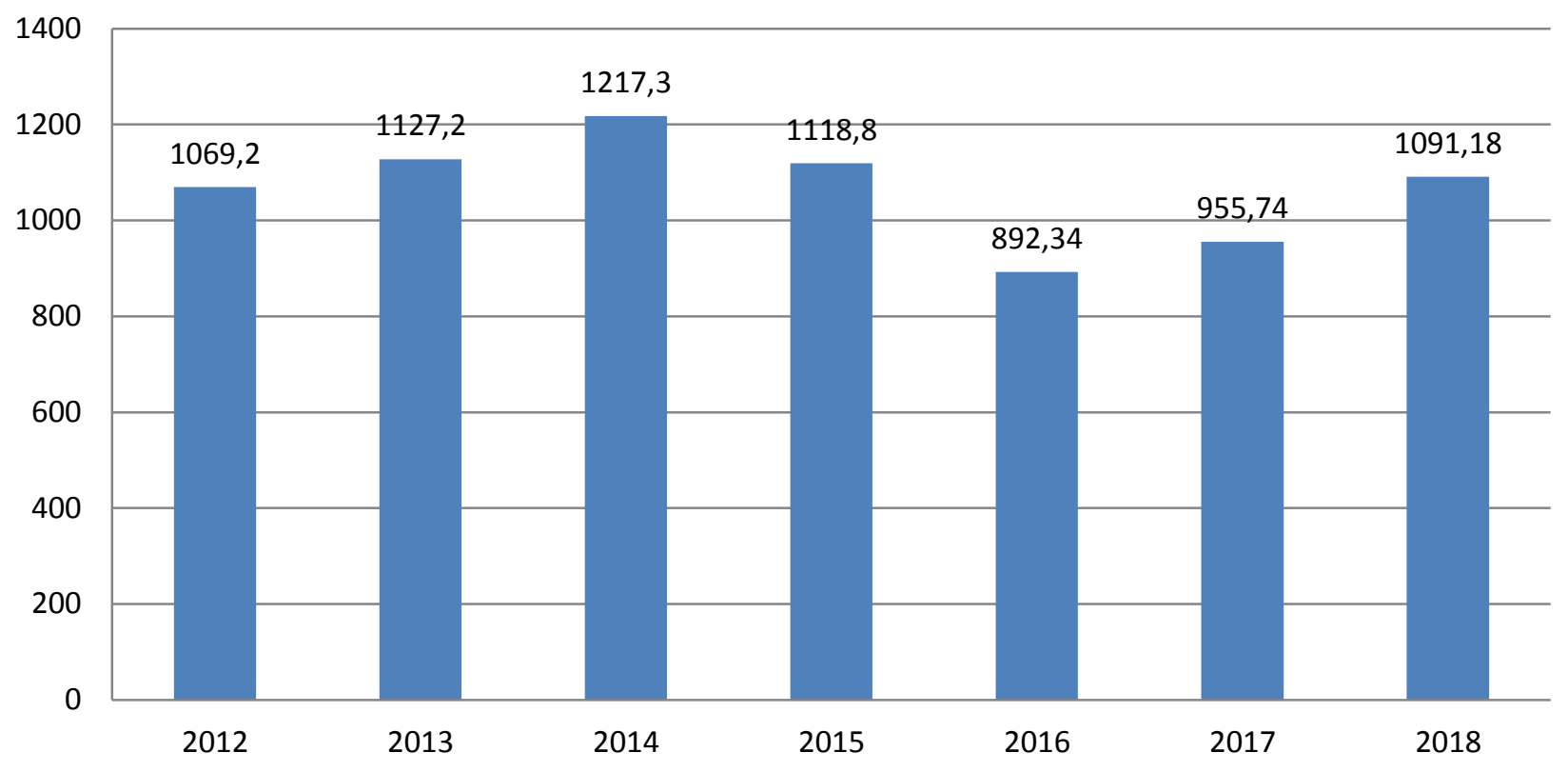

Fig. 1. Dynamics of exports of light industry goods for 2012-2018, million USD Source: calculated and constructed on the basis of data [4; 5]

Analyzing the dynamics of light industry goods exports for 2012-2018 (Pic. 1), we can see a positive trend in 2012-2014: the increase in exports of light industry products occurred from USD 1,069.2 million to USD 1,217.3 million, which is $13,85 \%$. In 2015-2016, light industry goods exports decreased by USD 98.5 million in 2015 and another \$226.46 million in 2016. The year 2017 was characterized by an increase in exports compared to the previous year, amounting to USD 63.4 million 
(7.1\%), which is positive for the development of the domestic light industry. The trend for 2018 was also marked by an increase in exports - an increase of USD 135.4 million $(11.73 \%)$.

Ukrainian light industry products are exported to 150 countries [3]. The main export items are textiles and textile products $-68.2 \%$, hats and shoes, fur and leather products - $31.8 \%$ (fig. 2).

The commodity structure of Ukrainian clothing exports is shown in fig. 3 .

More than $35.2 \%$ of Ukrainian exports went to EU countries, $5.1 \%$ to Egypt, $4.9 \%$ to Turkey, $4.4 \%$ to India, $4.2 \%$ to China.

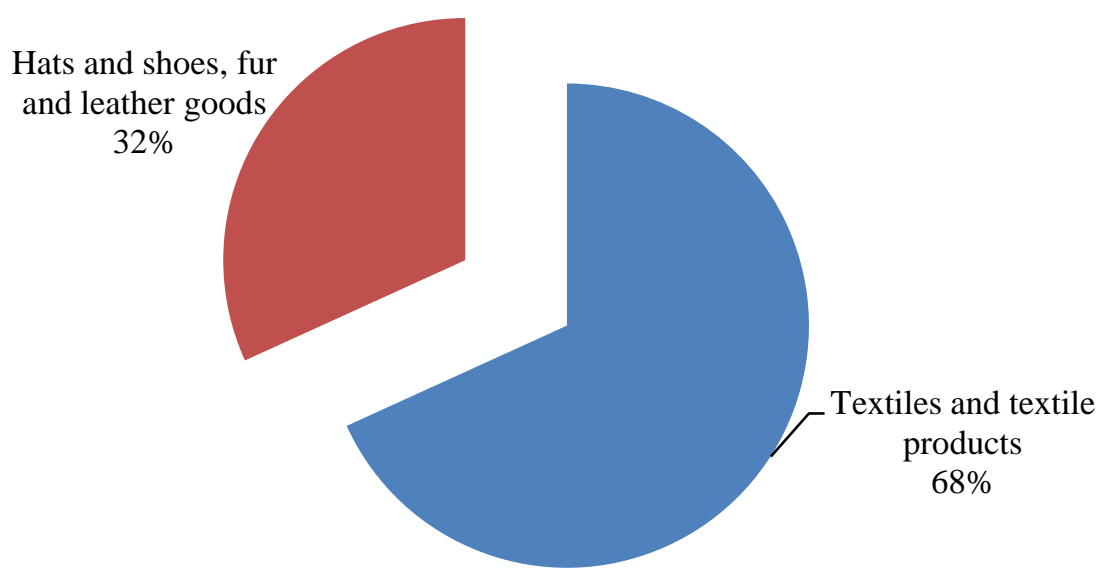

Fig. 2. Commodity structure of Ukrainian exports of light industry products in Source: data-based author [5] 2017,\%

Exports of light industry goods from Ukraine in March 2018 amounted to USD 102.5 million, which is $7.2 \%$ more than in February (in February it was at the level of USD 95.6 million). In terms of value, exports of light industry goods from Ukraine in the first quarter of 2018 amounted to USD 285.2 million. Compared to March 2017, exports increased by $19.9 \%$ [7].

In terms of product groups, comparing with February and March 2018, the largest increase was recorded in exports of threads and yarn $(+67.2 \%)$, footwear $(+$ $20 \%)$, leather and fur $(+19.1 \%)$.

The share of light industry exports in the total export structure in March 2018 was $2.525 \%$, which is a positive trend for the development of light industry. The structure of exports of light industry products in 2017 is shown in fig. 4. 




Fig. 3. Commodity structure of Ukrainian clothing exports in 2017,\% Source: compiled and constructed by the author on the basis of data [4; 5]

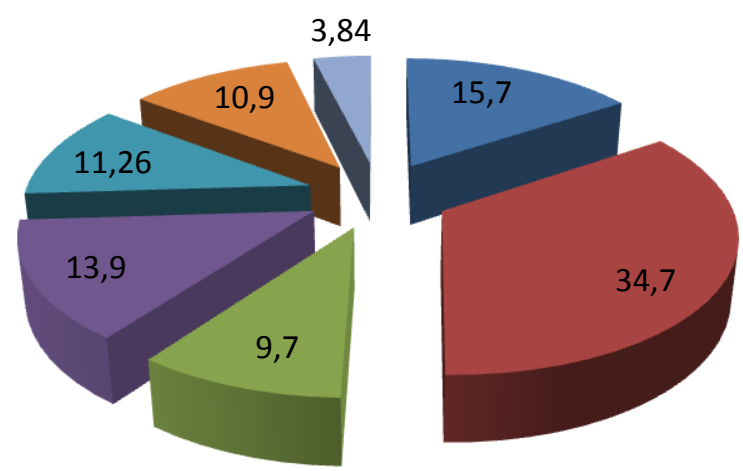

- Shoes and shoe parts

Clothes are textile

Knitted clothing

- Skins, leather goods, leather and fur clothing

- Silk, wool, linen, cotton, and garments, threads, jutes, cotton та ін. текстильні матеріали

Blankets, blankets, bed linen, dining room, curtains, curtains

Other

Fig. 4. Export structure of domestic light industry products in 2017,\% Source: calculated and built by the author on the basis of [4]

As we can see from fig. 4, one-third of all exported products consisted of textile clothing (34.7\%), shoes and footwear parts (15.7\%), hides and leather clothing (13.9\%), silk, wool, linen, cotton and clothing $(11,26 \%)$, knitwear $(9.7 \%)$, and other $(3.84 \%)$. 
The leading exporters of low-cost garment products in the world are important components of light industry in China, South Korea, India, Colombia, Taiwan. For this category of countries, the development of garment enterprises is considered as one of the main sources of economic growth, which provides several opportunities for intensification of development. The benefits of this activity are: low barriers to entry; the manufacturing process in many stages is technologically simple and laborintensive, which allows one to actively use a relatively low-skilled factor for the world's poor.

Ukrainian light industry products are exported to 150 countries [3]. The main export items are textiles and textile products $-68.2 \%$, hats and shoes, fur and leather products $-31.8 \%$.

The dynamics of imports of light industry goods for 2012-2018 are shown in fig. 5 .

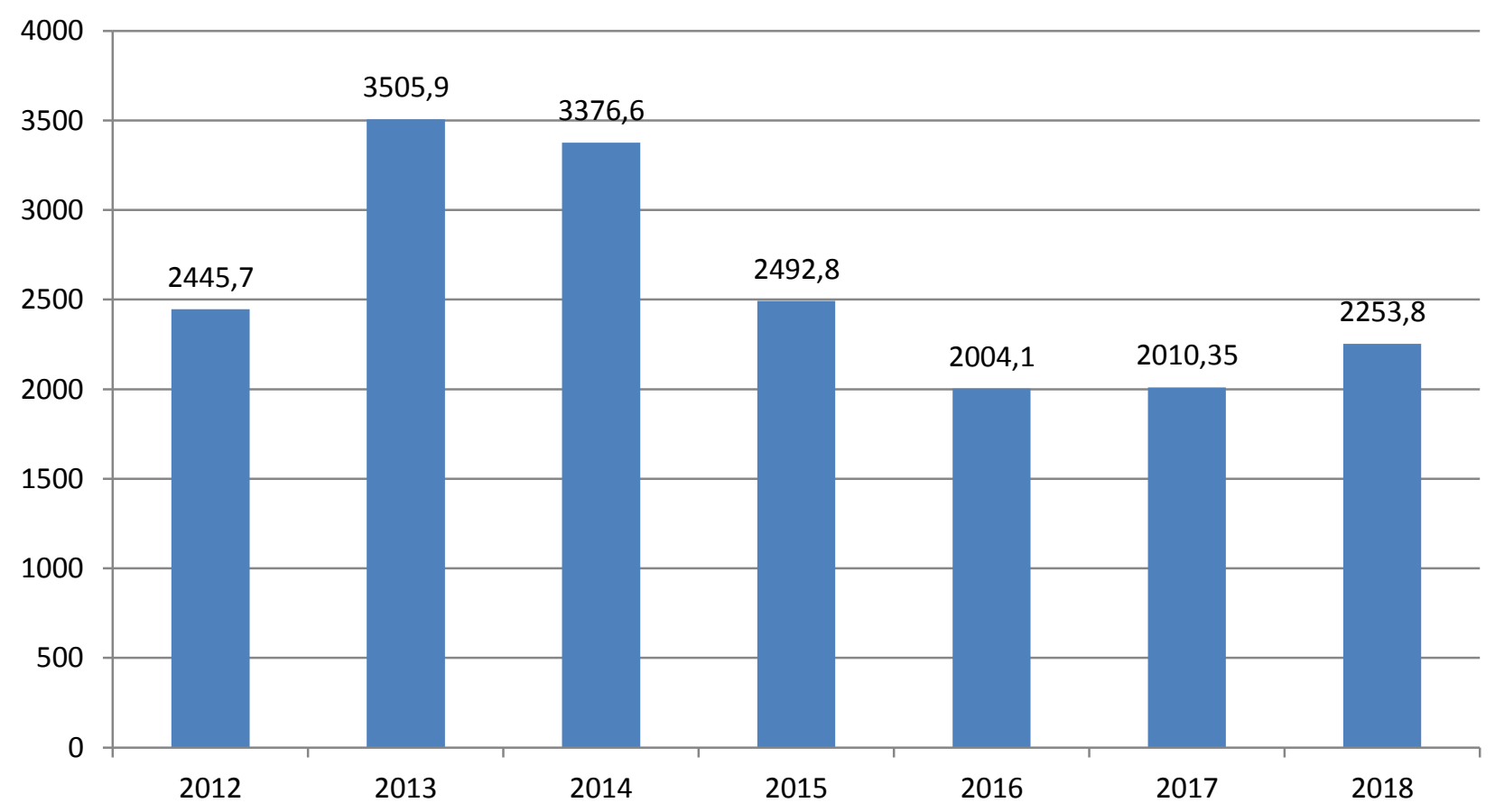

Fig. 5. Dynamics of imports of light industry goods for 2012-2018, million USD Source: calculated and constructed on the basis of data [4; 5]

Imports of light industry goods have been showing a positive trend for the domestic economy since 2013, declining from US USD 3505.9 million in 2013 to US USD 2004.1 million in 2016. Since the beginning of 2017, the downward trend in imports of light industrial goods has stopped: in 2017, the increase in the volume of goods by $0.31 \mathrm{pp}$ was typical, amounting to USD 6.25 million. At the beginning of 2018 , imports of light industry goods continued to grow at USD 2,253.8 million, or $12.1 \%$, comparing to the previous year, according to official data. 
In March 2017, light industry goods from Ukraine were exported for only USD 85.4 million. Exports of light industry goods to Ukraine in February 2018 amounted to USD 169.9 million, which is $5.6 \%$ more than in January (USD 161 million). At the same time, in February 2017, USD 155.2 million worth of light industry goods were imported into Ukraine. Thus, compared to February 2017, the volume of imports increased by $9.5 \%$.

On the whole, capital investments in textile, clothing, leather and other materials are increasing every year (fig. 6).

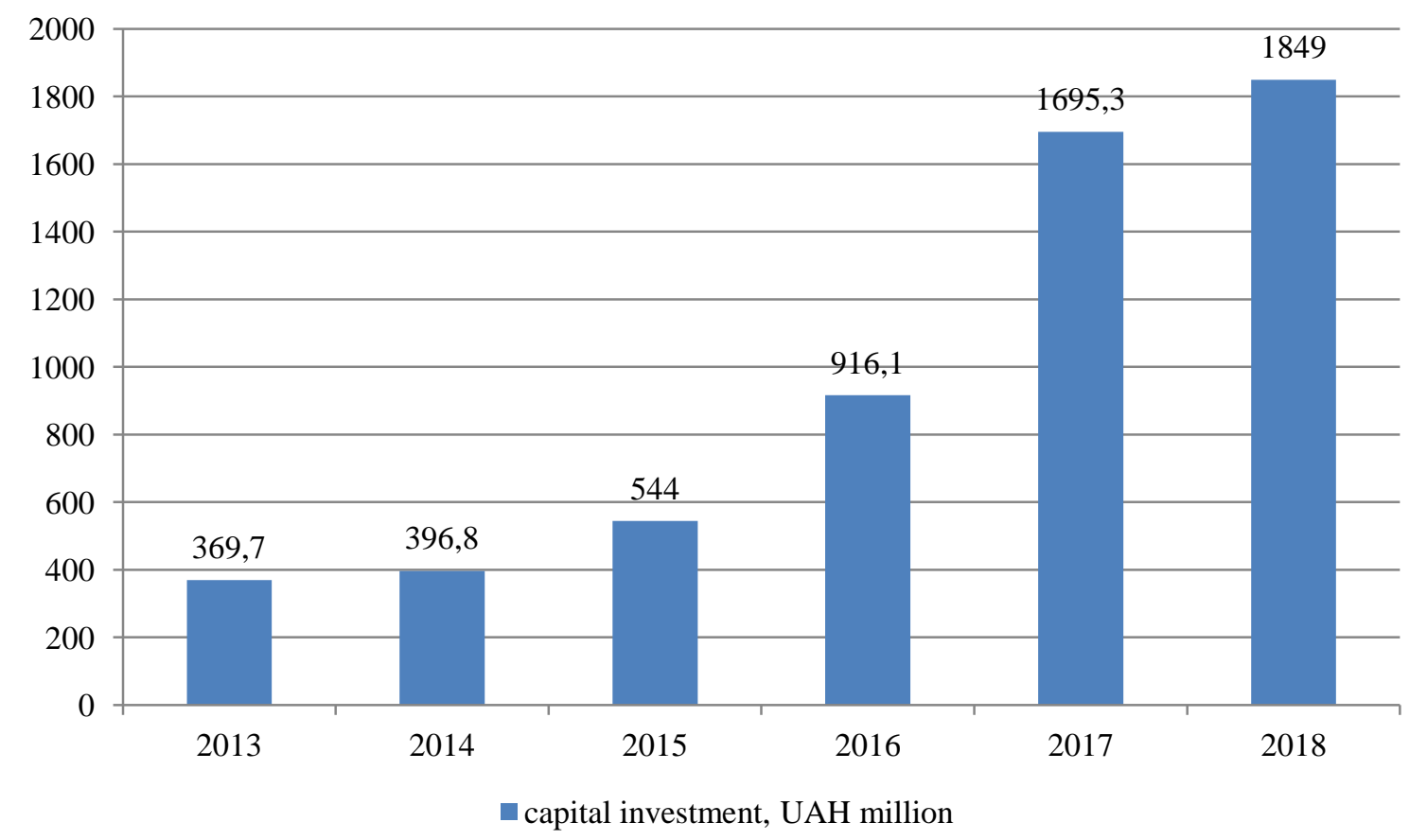

* data for the beginning of the period

Fig. 6. Volume of capital investments in domestic light industry for 2013 - 2018, million UAH

Source: by the author according to [4;8]

Despite the increase in the volume of capital investments, the financial results of the enterprises in the industry are deteriorating every year (Table 1). Thus, in 2017 the number of unprofitable enterprises increased by $9.44 \%$ and the number of profitable enterprises decreased by $14.04 \%$. As a whole, there is a decrease in the number of profitable enterprises and an increase in the number of unprofitable ones in the industry as a whole.

Analyzing 2013, it should be noted that the number of unprofitable enterprises in the industry increased by $3.82 \%$, while at the same time in the light industry there was a decrease of unprofitable enterprises by $23.05 \%$ and a profit increase by $5.33 \%$. 
Table 1. Financial results before taxation of domestic enterprises for 2013-2018, million UAH

\begin{tabular}{|c|c|c|c|c|c|c|c|}
\hline \multirow[b]{2}{*}{ Years } & \multirow[b]{2}{*}{$\begin{array}{l}\text { Financial result } \\
\text { before tax }\end{array}$} & \multicolumn{2}{|c|}{ Profitable enterprises } & \multirow{2}{*}{$\begin{array}{c}\text { Relative } \\
\text { deviation of the } \\
\text { financial result } \\
\text { to the previous } \\
\text { year, } \%\end{array}$} & \multicolumn{2}{|c|}{ Enterprises that received damage } & \multirow{2}{*}{$\begin{array}{c}\text { Relative } \\
\text { deviation of the } \\
\text { financial result } \\
\text { to the previous } \\
\text { year, } \%\end{array}$} \\
\hline & & $\begin{array}{c}\% \text { Of total } \\
\text { enterprises }\end{array}$ & $\begin{array}{l}\text { Financial } \\
\text { result }\end{array}$ & & $\begin{array}{l}\% \text { Of total } \\
\text { enterprises }\end{array}$ & Financial result & \\
\hline \multicolumn{8}{|c|}{ Total for the industry } \\
\hline 2013 & 21353,4 & 62,4 & 86504,1 & & 37,6 & 65150,7 & \\
\hline 2014 & 13698,3 & 63,3 & 81336,9 & $-5,97$ & 36,7 & 67638,6 & 3,82 \\
\hline 2015 & $-166414,0$ & 63,3 & 76253,3 & $-6,25$ & 36,7 & 242667,3 & 258,77 \\
\hline 2016 & $-181360,9$ & 72,9 & 90315,9 & 18,44 & 27,1 & 271626,8 & 11,93 \\
\hline 2017 & $-7569,6$ & 72,8 & 141475,3 & 56,64 & 27,2 & 149044,9 & $-45,13$ \\
\hline 2018 & 85429 & 71,6 & 227886,2 & 61,08 & 28,4 & 142456,7 & $-4,42$ \\
\hline \multicolumn{8}{|c|}{ Textile production, production of clothing, leather goods and other materials } \\
\hline 2013 & 125,4 & 63,5 & 559,6 & & 36,5 & 434,2 & \\
\hline 2014 & 255,3 & 66,7 & 589,4 & 5,33 & 33,3 & 334,1 & $-23,05$ \\
\hline 2015 & $-478,7$ & 69,5 & 1029,5 & 74,67 & 30,5 & 1508,2 & 351,42 \\
\hline 2016 & 867,6 & 77,2 & 1832,8 & 78,03 & 22,8 & 965,2 & $-36,00$ \\
\hline 2017 & 1641,2 & 77,0 & 2008,7 & 9,60 & 23,0 & 367,5 & $-61,92$ \\
\hline 2018 & 1324,5 & 72,8 & 1726,7 & $-14,04$ & 27,2 & 402,2 & 9,44 \\
\hline
\end{tabular}

Source: calculated by the author according to data [4] 
The crisis of 2013 contributed to the significant growth of unprofitable enterprises in 2014: thus, by industry as a whole, their increase was $258.77 \%$, and by light industry $-351.42 \%$.

In 2015, there was a $36 \%$ decrease in loss-making enterprises in the light industry, although in general, there was an increase in the industry $(+11.93 \%)$. The following year 2016 was characterized by a continued decrease in the number of unprofitable enterprises in the light industry by $61.92 \%$, whereas in the industry as a whole, this indicator amounted to $45.13 \%$. At the same time, in 2016, there was an increase in profitable enterprises: as a whole, by industry this figure was $56.64 \%$ in 2016 and in light industry $-9.6 \%$. The number of unprofitable enterprises in industry decreased in $2017-4.42 \%$, while the growth of profitable enterprises was $61.08 \%$.

Analyzing the profitability of operating activities in the industry as a whole and in the light industry (Table 2), it is possible to observe a tendency of its decrease in 2014 and increase in 2016.

For 2015, it was characterized by an increase in the profitability of operating activities for light industry enterprises and a decrease in the overall industry and processing industry in particular. The year 2017 was characterized by a $32.53 \%$ decrease in profitability from operating activities of light industry enterprises, while overall industry saw a $57.14 \%$ increase in profitability and $46.67 \%$ in manufacturing.

\section{Table 2. Profitability of operating activities of Ukrainian industrial enterprises} in 2012-2017

\begin{tabular}{|c|c|c|c|c|c|c|c|c|c|c|c|}
\hline \multirow{2}{*}{$\begin{array}{c}\text { Type of } \\
\text { industry }\end{array}$} & 2012 & 2013 & 2014 & 2015 & 2016 & 2017 & 2013 & 2014 & 2015 & 2016 & 2017 \\
\cline { 2 - 12 } & \multicolumn{4}{|c|}{ YEARS } & \multicolumn{4}{|c|}{ Relative deviation from previous year, $\%$} \\
\hline Industry & 3,5 & 3 & 1,6 & 0,9 & 4,2 & 6,6 & $-14,3$ & $-46,7$ & $-43,8$ & 366,7 & 57,14 \\
\hline Including: & & & & & & & & & & & \\
\hline $\begin{array}{c}\text { Manufact } \\
\text { uring } \\
\text { industry }\end{array}$ & 2,1 & 2,1 & $-0,6$ & 0,7 & 3,0 & 4,4 & - & $-128,6$ & $-216,7$ & 328,6 & 46,67 \\
\hline Including: & & & & & & & & & & & \\
\hline $\begin{array}{c}\text { Light } \\
\text { industry }\end{array}$ & 3,1 & 3,8 & 2,2 & 7,7 & 8,3 & 5,6 & 22,6 & $-42,11$ & 250,0 & 7,79 & $-32,53$ \\
\hline
\end{tabular}

Source: calculated and constructed by the author on the basis of: [4]

Ukraine's light industry, by its potential, is capable of meeting the demand of the population with products of sufficiently high quality, but because of irrational domestic policy, state policy in the sphere of regulation and a considerable amount of "second-hand" in the country is characterized by negative dynamics.

To improve the industry, light industry support measures should be implemented based on the following:

- improvement of institutional support, which envisages the adoption of regulations on the light industry development; 
- establishment of optimal / effective amounts of taxes and fees;

- expanding the volume of state purchases of goods (works, services) of light industry enterprises;

- providing financial support at all stages of economic activity, especially innovation;

- providing favorable conditions for entry into the market of domestic enterprises with new products;

- preventing the development of the shadow and smuggling market for light industry by restricting imports into the country and, in particular, second-hand goods;

- development of own material and raw material base, including through preferential taxation;

- the implementation of a guarantee by the state of lending to light industry enterprises.

The development of the light industry of Ukraine as a whole and the individual industry entities in particular is possible only at the expense of a constant and continuous flow of financial resources. The current economic conditions provide the independent determination of formation, mobilization forms and use of financial resources of economic entities. The rational choice of sources of financial resources and the justified determination of the optimal directions of their use is the key to the efficient use and quantitative growth of financial resources of light industry entities, which is one of the most important directions of financial policy of their development.

At the same time, the implementation of financial support for light industry entities in Ukraine occurs in the conditions of unstable economic development, which negatively affects the financial and credit sphere, lack of direct state financial support and proper management of their respective financing process through the financial infrastructure. This is what determines the urgency of addressing the institutional infrastructure improving issue for the formation of financial support for light industry entities.

Any business entity must be tailored to the environment in which it operates. In the process of developing light industry businesses, the level of adaptation is influenced by the selection of best practices that help to achieve a dynamic balance with the environment. There are two different types of adaptation of an entity to the environment: the first type is related to changes in the entity's structure and functions; the second type of adaptation relies on changes in behavior without changes in the subject's structure [9, p. 30].

Creating an entity begins with fixing and reproducing an already existing institutional matrix. This matrix contains formal and informal frameworks and institutions that must be matched by the scale and nature of the entity's business. Creating an entity in a certain aspect can be considered as a transformation "from 
external to internal" [9, p. 31]. The entity and the environment in which it operates are only responsive to one another, retaining their special nature. Their interaction and interdependence is, in essence, a process of asymmetric exchange in which institutions and structures act as the leading side [10].

The financial policy of light industry entities, which is focused on ensuring their development, is formed taking into account [11, p. 13]:

1) state policy in the field of financial support for light industry entities;

2) infrastructure financial support;

3) opportunities for expanding self-financing.

Institutional infrastructure of financial support for light industry entities is designed to create and implement effective mechanisms for creating an optimal system of access to financial resources, sources of their formation, opportunities to obtain them in the required amount and at the right time for the needs of functioning and development, and also in regulating their relationship with financial infrastructure institutions on mutually beneficial and acceptable terms. The most significant feature of this category is its role in creating general prerequisites for the reproduction process and general development conditions [12, p. 172].

Forming and properly distributing the financial support of light industry entities, while implementing the main provisions of the financial strategy and policies for their development, allows a developed institutional environment to function.

Institutional infrastructure is predominantly formal institutional constraints that determine possible organizational forms and options for economic interactions in particular economy areas and sectors. It is the institutional infrastructure that determines the specific rules and mechanisms of economic interaction, taking into account industry and other features of economic activity [13, p. 67].

Institutional financial infrastructure is a collection of financial institutions operating in the financial services markets, performing the functions of mobilizing, moving and investing resources. These institutions form the domestic economy financial sector and have a direct and indirect interest in ensuring the rational and efficient use of financial resources. But there is another problem - aligning the financial institutions' own interests with those of the owners of these resources: although they are largely the same (each entity wants to maximize profits), controversy may still arise. Taking into account such specificity of financial institutions, their activity is obligatory regulated by the state in the person of regulatory bodies and the central bank [14].

The business entity's institutional environment is an orderly system of institutional system elements that have binding rules, criteria, and prescriptions for the entity, and therefore directly or indirectly limit the field of available rational choice alternatives. 
We believe that the support of the institutional infrastructure for the development of light industry entities is carried out at the macro, meso and micro levels, and therefore the priority tasks of such support should be considered at these levels. At the same time, it is advisable to divide the institutional infrastructure entities into external (state and sectoral level) and internal (entity level). The components of the institutional financial infrastructure and its instruments are shown in Fig. 7.

The state is interested in the light industry entities being deeply modernized, in order to innovate and develop their human resources. Support of businesses development may be in the following areas:

1. Improvement of state financial support for the development of light industry.

2. Improvement of opportunities for financing the development of light industry entities at the expense of the financial resources of financial and credit institutions.

3. Expansion of opportunities for financing the development of light industry entities at their own expense.

Therefore, the priority tasks of state support in improving the institutional environment of the financial infrastructure of light industry entities should be:

1. At the macro level, it must be the creation of various horizontal mergers of enterprises for joint investment and production projects and industry preferential taxation.

According to the Economic Code of Ukraine, associations of enterprises are called economic ones, created to coordinate their production, scientific and other activities in order to solve common economic and social problems [15]. The benefits of combining businesses into a single structure include the following:

- variability of structural restructuring and establishment of industrial and technological links, which, through coordination and coherence of activities between all branches of management networks within the association, help to attract financial resources for the development of business entities;

- joint lobbying of common interests;

- transfer of capital from less promising types of economic activity to more promising ones; that ensures the implementation of complex economic projects (in case the company does not have sufficient financial resources, it is possible to obtain credit from partners on favorable terms or attract investments);

- interconnected development of science and technology, which promotes the integrated use of raw materials and energy resources, especially in the case of association with a design or research organization [17, p. 229]. 


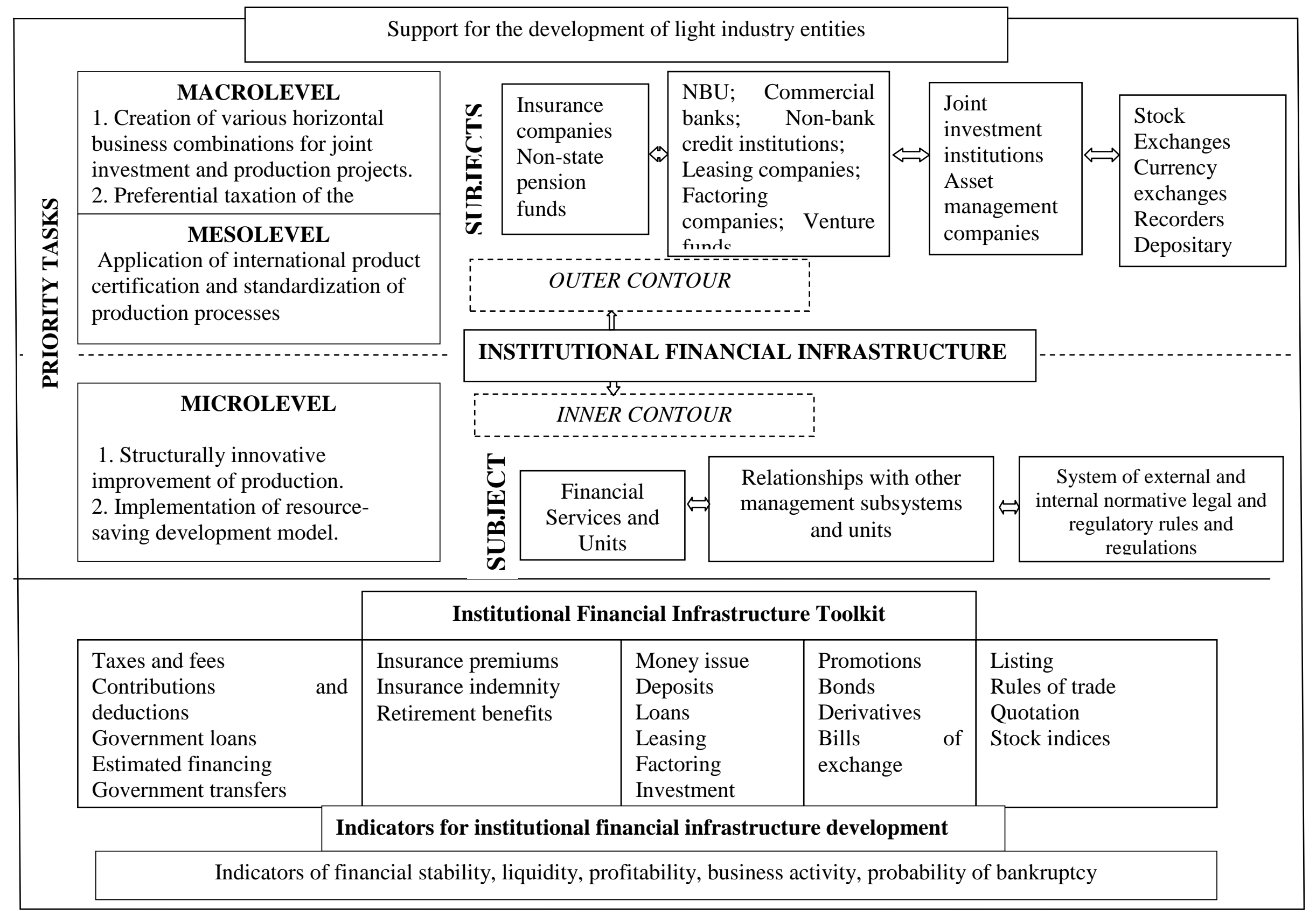

Fig. 7. Components of institutional financial infrastructure and its instruments 
An argument for enterprise integration is the example of well-functioning associations such as Mitsubishi, Mitsui, Sutimoto, Hyundai, Samsung, Deu and others. These enterprises provide a significant volume of production and sales of products both in the territory of the country and abroad, increasing its share of export in the world market.

Nowadays, the Government of Ukraine plans to start new businesses and increase the average wage of industry workers by $30 \%$. One step in this direction is the adoption of a package consisting of 35 bills that will help protect the light industry and access resources. In addition, the country introduced a two-year installment payment for VAT on the import of equipment [18, p.116].

It is important to note that Ukraine is obliged to adapt the system of state support (assistance) of economic entities in accordance with the system of state aid monitoring and control at the request of Ukraine to fulfill its obligations under the Association Agreement signed in 2014. Integration into the EU compels international standards on state support for business.

State support policies should be limited to ensuring that conditions are conducive to the ongoing development of business entities. Therefore, in determining its essence we should proceed from the following:

- financial support is a component of state regulation;

- support of business entities is beneficial not only to the business entities themselves, but to the entire economy and the state as a whole.

State aid is, actually, an effect on competition and trade in the form of subsidies, tax breaks and other forms of government concessions for the benefit of certain enterprises, and may therefore have an adverse effect on other entities. However, as far as support is concerned, in every country (including all EU and WTO countries), economic support is supported to a greater or lesser extent (such as support of industrial sectors, certain firms, regional development, innovation, investment, trade, small business), as well as key industries such as light industry, defense industry, transport, agricultural sector) by introducing various instruments, including subsidies, tax breaks and other measures that have less direct impact.

Thus, the prerequisites for the financial support of the activities of light industry enterprises, as the basis for their effective development, are laid down by state policy, which provides the regulation of organizational principles related to the creation, registration, choice of the taxation system by an entity, etc. Appropriate measures of the state are aimed at the development of light industry and determine the possibilities, structure, terms and forms of external and internal sources of financial resources of economic entities use. Existing problems of practical implementation of financial support require reforms that should be aimed at developing support of light 
industry entities by financial infrastructure entities. The important steps in this direction are:

- budget financing of research, development and research works, development of new technologies;

- introduction of centralized planning in the industry, which will help to calculate the required quantity of manufactured products for the needs of the economic entities of industry and the partner companies, which will help to reduce the filling of the domestic market with imported goods and increase the number of goods of light industry of own production;

- development of a coherent government policy towards consolidation of the state budget funds, economic entities' own funds, as well as loans and attracted investments;

- lower prices for raw materials and energy for light industry entities, which will reduce the cost of production and reduce the imbalance between commodity prices and purchasing power of the population;

- simplification of customs procedures for economic entities subject to giving schemes and export of products;

- the allocation of targeted financing for the industry, which will reduce the volume of work under tolling schemes.

On the meso level, the priority, in our opinion, is to apply international product certification and standardization of production processes.

Standardization is the organizational and technical basis of economic, scientific and technical cooperation between countries, an effective means of expanding ties in international markets and eliminating technical barriers to international trade. Strengthening scientific, technical and economic ties draws attention to the standardization of all developed countries and developing countries, as well as technical, economic, international, regional and national organizations, firms and enterprises. This is a consequence of the objective need for standardization in the management of economic and production processes.

This will allow light industry entities to increase business activity, increase their share in aggregate and regional GDP, increase employment and productivity of the active population, and promote industry development.

At the micro level, the priorities are:

1. Structurally-innovative improvement of production.

Structurally-innovative improvement of production should be carried out by:

- realizing the competitive advantages of individual industries whose products are in high demand, applying international quality standards;

- accumulation and further use in the production of scientific, technological, resource and intellectual potential. 
2. Implementation of resource-saving development model.

An important area of development of light industry in Ukraine is the introduction of innovative processes in its activity, which allow the industry to be low-tech production, that is, resource-saving, which will allow to produce competitive products of high quality at a relatively low price. Businesses in the production of fabrics, clothing and footwear must constantly expand and update their range, ensuring high quality products, focusing on the needs of consumers of different ages and fashion trends of Ukraine and the world.

The current economic situation of the Ukrainian economic system determines not only the expediency, but also the necessity of its movement to resource saving, to the type of production, which requires increasing the efficiency of use of all without exception types of resources: material, energy, technical and technological, financial, information, labor, intellectual. The resource-saving model of light industry development will allow the economic entities of the industry to reach an equal forecasted state, increase their market potential, and attract real credit investors. Such a model becomes one of the key factors for market success, which is a major competitive advantage in the system of finding new opportunities for developing the financial capabilities of light industry entities.

The financial policy implementation of light industry entities development depends directly on the support of the financial infrastructure. The subjects of financial infrastructure of the light industry include: banking system (National Bank of Ukraine and commercial banks), non-bank credit institutions, leasing and factoring companies, venture capital funds.

The securities market is extremely important for the formation of business entities' capital. The priority of the securities market is to provide the conditions for attracting investments by companies, access of economic entities to cheaper capital compared to other sources, as well as attracting and redistributing capital in those sectors of the economy, where this is necessary from the point of view of economic feasibility.

Co-investment institutions are important investors of business entities, since their sole activity is to invest in various sectors of the economy in order to generate and distribute profits among investors [18, p. 118]. In Ukraine, at the legislative level, there are two types of joint investment institutions, which, depending on the order of creation and operation, are divided into corporate investment funds and mutual funds. A significant role in the activity of joint venture institutions is played by the asset management company of the joint venture institutions, since the KUA ICI is a legislator with the function of managing the assets of investment funds. 
Audit and information consulting firms, appraisers, actuaries are service organizations in the institutional infrastructure of financial support for light industry entities.

Infrastructural institutes and service organizations promote the cooperation of light industry entities with other components of the infrastructure, form a system of economic relations and have a direct impact on the activity of the support infrastructure of light industry entities (clusters, business incubators, network structures, etc.). Modeling the possibilities of financial support for the light industry entities development at the expense of the financial resources of financial and credit institutions requires:

1) improvement of organizational and coordination activities of regional authorities aimed at increasing the volume and improving the efficiency of bank lending to the development of light industry entities (a large part of which are small and medium-sized enterprises). Thus, regional guarantee funds can be created on loans (with parity financing of funds from local budgets, financial and credit sector entities, business associations, trade entities), with the aim of diversifying risks when attracting large investment projects of sponsoring firms (guarantor firms) with motivation to generate income from the project implementation or business expansion, to create a system with the formation of delivery or sales channels;

2) enhancement of the investment attractiveness of the region territories, which will enable to attract investors;

3) improving the institutional environment by accumulating investment and coordinating integration processes, including the creation of investment parks;

4) intensification of insurance institutions participation in providing access of light industry entities to financial and credit resources. One of the mechanisms in this direction in the developed countries of the world is the creation of insurance guarantee funds in the form of non-profit state or communal organizations.

Of course, state and infrastructure financial support for light industry is crucial and provides opportunities to create conditions for the development of economic entities of the industry, but the measures they have implemented must find adequate implementation and continuation directly at the level of economic entities. Moreover, business entities also have some arsenal of tools for their development.

Important in this direction is the creation (or ordering) of an internal corporate institutional infrastructure for financial management, which consists of financial services and units, relationships between them and other management subsystems and structural units, systems of external and internal normative legal, regulatory and methodological regulations and rules of behavior. Its "strengths" are: financial and human resources, ability to cooperate with financial institutions, clients, suppliers, manufacturers, intermediaries, providers of marketing, logistics, outsourcing services, 
quality of financial and investment activity, quality of marketing activity and strategic decisions. The activity of such internal infrastructure within the financial support of light industry entities determines the sources of financial resources and their distribution within the enterprise.

The development-oriented activities of a lightweight business entity's in-house financial infrastructure may include actions such as an analysis of the potential adverse financial consequences of the marketing development, commercial subsystems of the entities regarding the condition and changes in profitability, financial soundness and liquidity; studying the securities market regarding the attractiveness state of economic entities securities to attract financial assets and investments for the development of economic entities, as well as the protection of shares from unauthorized seizure and control over the assets of the economic entity; evaluation of investment projects on similar parameters; study of commercial and business offers, etc.

An important feature of the financial infrastructure of light industry at the present stage should be the creation of wholesale distribution networks, which will increase the volume of exports of clothing, footwear, textiles.

Extension of financial support capabilities of light industry entities in the context of improving institutional infrastructure is carried out at mark and level, taking into account the state financial and infrastructural support and capabilities of micro-level inter-company infrastructure.

Thus, the given scientific and practical recommendations for modeling the institutional infrastructure of light industry entities are to justify the need to create various horizontal associations of enterprises for joint investment and production projects and preferential taxation of the industry - at the macro level; the application of international product certification and standardization of production processes - at the mesolevel; structural and innovative improvement of production and implementation of the resource-saving model of development - at the micro level, will help to strengthen the role of the infrastructure component in ensuring the financing of light industry entities.

\section{Reference:}

1. Konoval V.V. (2014). Assessment of light industry development potential. Scientific Bulletin of Kherson State University. Issue 6. Part 2. pp. 167.

2. Mirko N.V. (2010). Assessment of the state and tendencies of development of the domestic market of light industry products. Effective Economy № 10.

3. Light Industry of Ukraine: Realities and Prospects. Retrieved from: https: //uteka.ua/en/publication/Legkaya-promyshlennost-Ukrainy-realii-i-perspektivy.

4. State Statistics Committee of Ukraine: official site. URL: http://www.ukrstat.gov.ua

5. Ministry of Economic Development Retrieved from: http://www.me.gov.ua/Documents/Detail?lang=enUA\&id=112a480c-9492-4736-99ed-b0f3b1152c27\&title=SpriiatliviUmoviDliaBusiness.2.

6. Denisenko, M.P. (2015) Innovative potential of Ukraine: experience and problems / MP Denisenko. Scientific notes of KROK University. Series: Economics. №40. P. 10-19. Retrieved from: http://nbuv.gov.ua/UJRN/Vzuk_2015_40_4. 
7. Ministry of Economic Development and Trade (MEDT) of Ukraine citing SE "State Information Service" Retrieved from: http://www.me.gov.ua/?lang=en-UA.

8. Seliverstova L.S. (2017), Mikh O.M. State and prospects of development of light industry of Ukraine. Formation of market relations in Ukraine. №4 (191). Pp. 52-57.

9. Business Development Management: Monograph (2008) [ed. col.: O. L. Yaremenko, O. M. Pankratova, etc.]; for the total ed. of O. L. Yaremenko, G. V. Strokovich; Nat. Ukr. Acad. Kh.: View of NUA. 500 p.

10. Denysenko, M.P. (2013). Strategy of economic development of Ukraine: investment-innovative aspect. Effective Economy. № 1. Retrieved from: http://nbuv.gov.ua/UJRN/efek_2013_1_58.

11. Hodgson, D. (2003) Economic theory and institutions: A manifesto of modern institutional economic theory / D. Hodgson; [trans. with English]. 464 p.

12. Financial support of business development: monograph (2011). Edited by Ph.D. of sciences, prof. I. O. Blank. Kiev. KNTEU. 343 pp.

13. Volchik, V.V. (2009). The hierarchy of institutions within the economic order. Terra Economicus. Vol. 7, №2. P. 65-73.

14. Fedosov, V.M. Theory of finance. Components of financial infrastructure. Retrieved from: https://westudents.com.ua/glavy/100516-14-skladov-fnansovo-nfrastrukturi

15. Economic Code of Ukraine. Retrieved from: http://zakon3.rada.gov.ua/ laws/show/436-15

16. Adamenko, I.P., Seliverstova L.S. (2018). Features of development of the financial market of Ukraine. Investments: Practice and Experience. №9. P.13-17.

17. Bondarenko Yu.G. Business integration as a mechanism for increasing the efficiency of investment activities in the region. Retrieved from: http://ena.lp.edu.ua: 8080/xmlui/handle/ntb/31543.

18. Seliverstova L. S, Parkhatska O.M. (2018). The mechanism of financial policy making to ensure the effective development of business entities. Determinants of socio-economic development of Ukraine in the context of transformational shifts: a collective monograph / by General. ed. Ph.D. of sciences, prof. VP Ilchuk. Chernihiv: National Technical University, 2018. 432 p. P. 111-126. 